\title{
Re-thinking the Incrementalist Thesis in China: A Reflection on the \\ Development of the Minimum Standard of Living Scheme in Urban and Rural
}

\section{Areas}

\section{CHAK KWAN CHAN}

Reader in Social Policy, Division of Criminology, Public Health \& Policy Studies, Nottingham Trent University, Burton Street, Nottingham NG1 4BU. Email: chakkwan.chan@ntu.ac.uk

\section{Abstract}

Many commentators contend that the Chinese government adopted an incremental approach to welfare policy reform because its leaders lacked an overall blueprint for it, allowing initiatives to be implemented only after lengthy experimentation. While this perspective has provided an essential account of the implementation and changes of some welfare programmes, it has inadequately addressed the slow progress in rural areas' welfare programmes and the different welfare entitlements for rural and urban residents. Further investigation is therefore required to resolve these anomalies. Using the minimum standard of living scheme (MSLS) as a case example, this article illustrates how the Chinese government's legitimacy needs during different stages of its economic reforms have been the principal motivation for the implementation of such schemes. The introduction of an urban MSLS in 1997 aimed to reduce laid-off workers' dissatisfaction following the government's reforms of state-owned enterprises (SOEs). The implementation of a rural MSLS in 2007 principally intended to minimise conflicts between land-losing farmers and local officials after widespread rural riots. These MSLSs are also minimal and stigmatising public-assistance schemes that fulfil the dual objective of securing a stable political 
environment for economic reform and maintaining poor people's work ethic for China's mixed economy.

Key words: legitimacy, economic reform, MSLS, laid-off workers, land-losing farmers.

\section{Introduction}

The implementation of a household responsibility system in 1981 and the introduction of state-owned enterprise (SOE) reforms in the 1980s completely destroyed the financial base of communes and work-units, China's two fundamental welfare units. Unemployment did not exist in China before its economic reforms because the Chinese government assigned jobs to people in order to achieve the goal of full employment. It stopped this practice in the 1980s, however, when it adopted policies aimed at reducing the financial burden of state enterprises and improving their productivity. It also introduced a bankruptcy law in 1986, which allowed SOEs to declare bankruptcy. This meant that some SOEs would disappear and that the government had abandoned its full-employment policy (Li, 2001).

China's economic reforms therefore resulted in many people becoming unemployed. More than 200 million workers became redundant in rural areas (Nielsen et al., 2005) and about 3.8 million workers in urban areas became unemployed (Gang et al., 1998). Unfortunately, during the early reform period the central government failed to work out a comprehensive social security programme for meeting poor people's financial needs, with only a few provincial governments attempting to introduce some organised and stable social assistance schemes to address local circumstances. The Chinese government finally introduced a minimum standard of living scheme (MSLS) to provide long-term financial support for poor urban residents in 1997. Rural poor people, however, had to wait another ten years to see a similar scheme established in 2007. Using the MSLS as an example, this article argues that 
China's welfare development needs to be studied to some extent from the perspective of the Chinese government's responses to legitimacy crises caused by its SOE reforms and local authorities' public land acquisitions.

\section{The incrementalist thesis and its limitations}

Many studies have pointed to China's economic reforms as being gradual and incremental (Otsuka et al., 1998; Lou, 1998; Chow, 1999; Gao, 1999; Qian and Wu, 2003; Chen, 2004; Choi and Roy, 2006). Some academics further claimed that China's gradual economic approach has also been extended to its welfare provision. In regard to housing policy, Chen noted that 'The designs of government reform policies, however, manifested a large degree of continuing intervention under the gradual reform scheme' (2004: 73). Wong et al. also stated that 'health care reform in China has been a gradual process carried out in piecemeal steps' (2005: 95).

Choi and Roy, among others, have believed that the Chinese government used a gradual approach because it lacked any examples for transforming a socialist economy to a mixed economy, pointing out that:

To begin with, the Chinese leaders did not have an overall reform blueprint from the outset, and thus had to proceed with the reforms in a very cautious manner. Second, reform cannot be rushed before the necessary conditions for its successful implementation have been met. (2006: 49)

Lou held a similar view, stressing that 'China experimented in some areas, and its experience thus gained guided the reform' (1998: 149).

The welfare disparities between cities and the countryside, however, challenge the validity of the incrementalist thesis. In regard to old age protection, for example, urban workers are 
legally required to join an old-age pension scheme, while peasants' participation is voluntary. As a consequence, over half of all retired urban workers received old age benefits in 2000 , in contrast to fewer than 10 per cent of retirement-age rural residents receiving them (Wang, 2005). Differences have also existed between cities and the countryside in regard to healthcare spending. The per capita health expenditure in cities was $¥ 1,262$ compared with only $¥ 302$ in rural areas in 2004 (Ministry of Health, 2006). Education policy has also discriminated against rural people. Before 2006 the children of migrant workers in cities could only attend private schools, so as many as 9.3 per cent of them did not receive education because of poverty (People's Daily Online, 2006). Such welfare disparities between people in cities and the countryside have 'created two welfare systems serving two groups of Chinese citizens sharing the same nationality' (Chan et al., 2008: 86).

Nevertheless, the incremental perspective has made two major contributions in pulling together the key feature of China's welfare system and explaining the gradual transformation of some welfare programmes. For example, the Shanghai municipal government originally developed the MSLS in 1993. Later, such cities as Guangzhou, Dalian, Qingdao and Fuzhou established similar schemes. Then the central government encouraged other provinces to launch the scheme in 1995.

While providing us with valuable information on the processes of welfare implementation, the incrementalist thesis has underplayed the importance of politics in pushing policy changes. In particular, it has ignored the impact of social unrest in contributing to the creation of new services and has also underestimated the role of class politics in widening welfare disparities. For example, the development of China's old-age pension scheme was the result of political bargaining between the Ministry of Labour and the Economic Structure Reform Commission. The former pursued a scheme based on the principle of social fairness, 
while the latter, supported by the World Bank, urged one implemented according to principles of economic efficiency. As White et al. pointed out, 'These various interests and constituencies have shaped the trajectory of pension reform over the past decade' (1998: 211). As the incrementalist thesis has explained the existence of the two welfare systems and class inequalities in modern China inadequately, an alternative approach is badly needed to address these issues.

\section{Legitimacy and social policy}

According to neo-Marxists, capitalist states always have to manage the contradictory tasks of facilitating capital accumulation and maintaining political legitimacy (O'Connor, 1973; Habermas, 1976; Offe, 1984). According to Habermas (1976), the human world is composed of economic, political-administrative, and sociocultural subsystems. The principle of organisation in a liberal capitalist state is 'the relationship of wage labour and capital, which is anchored in the system of bourgeois civil law' (Habermas, 1976: 20), and the main function of a capitalist state is to 'maintain the general conditions, which make possible the market-regulated process of capital realisation' (Habermas, 1976: 21). This means that capitalist states have to ensure that 'the capitalist social system is allowed to continue and to be reproduced again and again over time' by protecting commerce and by providing a legal framework and updated infrastructure for capitalist production (Best, 2002: 26). However, the economic crisis of capitalism always threatens capitalist societies' social and political stability. Habermas explained that:

For liberal capitalism, the fluctuation of prosperity, crisis, and depression is typical. The opposition of interests, which is grounded in the relation of wage labour and capital, 
comes to light, not directly in class conflicts, but in the interruption of the process of accumulation, that is, in the form of steering problems. (1976: 23)

Any state attempts to deal with the crises of one subsystem, however, may result in the 'transformation and displacement of inherent contradictions into another' (Pusey, 1987: 95). In short, a government which tries to solve an economic crisis by reducing taxation and welfare expenditure is likely to increase its 'legitimation deficit' (Pusey, 1987: 95), thereby creating 'a social crisis in which the interests of acting groups collide and place in question the social integration of the society' (Habermas, 1976: 29-30). An economic crisis, therefore, is likely to lead to social and political crises if state interventions are inappropriate.

In line with the idea of the contradictory nature of a capitalist state, O'Connor pointed out that:

the state must try to maintain or create the conditions in which profitable capital accumulation is possible. However, the state also must try to maintain or create the conditions for social harmony. A capitalist state that openly uses its coercive forces to help one class accumulate capital at the expense of other classes loses its legitimacy and thence undermines the basis of its loyalty and support. But a state that ignores the necessity of assisting the process of capital accumulation risks drying up the source of its own power, the economy's surplus production capacity and the taxes drawn from its surplus (and other forms of capital). (1973: 6)

Piven drew our attention to the legitimacy function of social assistance, emphasising that 'mass unemployment leads to outbreaks of turmoil [so that] relief programs are ordinarily initiated or expanded to absorb and control enough of the unemployed to restore order' (1973: 271). 
Governments have always used social welfare programmes to enhance political legitimacy. In Singapore, a universal housing programme was a 'foundation stone' for building the legitimacy of the People's Action Party among Singaporeans (Chua, 1997: xi). In Korea, the military government in the 1960s tried to 'raise its political legitimacy' by passing three welfare laws, including the Industrial Accident Compensation Insurance Law, the Medical Insurance Law, and the Social Security Related Law (Shin, 2003: 63).

China's economy is now mixed rather than socialist. As The Economist (2004) reported, 'China's leaders still call themselves communists, but they have become capitalist in practice'. In the early 1990s, a Chinese economist from the University of Chicago even claimed that 'China had already become essentially a market economy' (Chow, 1994: 36). The Chinese government, like other capitalist states, needs to secure a safe environment for economic development. Chinese leaders therefore tried to avoid issues threatening social and political stability during the reform period (Cai, 2002).

More importantly, 'China is not a democracy' (Gries and Rosen, 2004: 6); and the Chinese Communist Party (CCP) always needs to consolidate the foundation of its legitimacy, especially after the implementation of the economic reforms of 1978. During the Mao Zedong period, the Chinese Government's legitimacy rested on 'an explicit belief that China's future lies in communism' (Kluver, 1996: 2). However, this belief had been almost completely destroyed by non-stop class struggle campaigns and poverty before the death of Mao. Even the most prosperous rural populations 'had been reduced to beggars' and the whole country was 'in a state of depression and despair' (Ding, 1994: 1). Thus, the post-Mao ruling elite under the leadership of Deng Xiaoping tried to use economic development to strengthen the CCP's legitimacy (Guo, 2003). This strategy has achieved an outstanding result as China's per capita GDP jumped from US\$190 in 1978 to \$2,360 in 2007 (American 
Chronicle, 2009). On the other hand, the privatisation of social services and the unbalanced economic development between cities and the countryside have widened the wealth gap between the rich and the poor. China's Gini coefficient rose from 0.257 in 1990 to 0.447 in 2005 (Euromonitor International, 2007). Inequality has directly damaged the image of the $\mathrm{CCP}$, which rose to power by promising the masses an equal society. Without implementing Western-style political reform, the CCP has to justify its rule by improving the welfare of all Chinese people, regardless of class origin' (Lam, 2006: 36). Shue (2004: 34) pointed out that China's leaders have attempted to consolidate their legitimacy by practising 'human benevolence'. Similarly, Guo (2003) noted that China's president Hu Jintao is using the philosophy of 'governing for the people' to address the problems in economic equality and social justice. As 'no state can survive for long by force alone' (Gries and Rosen, 2004: 6), the Chinese Government has therefore used public welfare as a means of minimising social conflicts and maintaining political stability. However, the role of legitimacy in China's welfare provision has been under-researched and under-reported. This article therefore critically examines the relationship between social unrest and the development of the MSLS in urban and rural areas.

\section{SOE reform and urban unrest}

The establishment of a national urban public assistance scheme in China was a consequence of SOE reconstruction. The Chinese government accelerated its economic reforms by introducing a socialist market economy following the Third Plenum of the Fourteenth Party Congress (Chinese Communist Party Central Committee [CCPCC], 1993). This suggests that the Chinese government shifted its economic strategy from increasing the work incentives of factory managers and workers in the 1980s to the reconstruction of the ownership and management of SOEs in the 1990s. The new strategy's overall objectives were to 'set the 
goal of transition to a market system', to 'establish market-supporting institutions incorporating international best practices', and to 'privatise and restructure state-owned enterprises' (Qian, 1999: 14). This means that the government expected SOEs to be market players guided by modern management methods similar to those of private companies. This policy resulted in the forming of such new types of companies as shareholding enterprises, listed companies, enterprise groups, limited liability firms, collectives, private firms and foreign-invested enterprises (Green, 2004).

SOE reform, however, had caused large-scale redundancies that directly threatened the livelihood of hundreds of thousands of workers. Before China's economic reforms, young urban people were assigned jobs at work units (danwei), from which they received a wide range of social services such as medical care, housing, pensions and childcare. A work unit was therefore a 'miniature society' (Plone Foundation, 2008), functioning like a 'mini-welfare state' (Leung and Nann, 1995: 57). After the implementation of the SOE reforms, however, urban workers faced unemployment and the suspension of pay and benefits. From 1993 to 1998 the number of laid-off workers jumped from 3 million to 17.24 million (Cai, 2002). Many laid-off workers found it difficult to get new jobs because they had low qualifications. According to the State Statistical Bureau, 61 per cent of the laid-off workers had only a junior secondary-school education or less, and 18.5 per cent of them were over 45 years old (Solinger, 2002). A senior officer from the Ministry of Labour and Social Security pointed out that among the 21 million laid-off SOE workers who had gone to re-employment service centres (RSCs), 6.6 million were unable to get new jobs (Hong Kong Trade Development Council, 2001).

The central government's strategy could not handle the laid-off workers' problems effectively. It provided a three-year transitional period for them, during which they could 
enter RSCs to receive employment training and obtain a basic living allowance. However, many SOEs had 'either gone bankrupt or were suffering serious losses and deeply in debt' (Solinger, 2002: 315), so they had insufficient resources either to set up RSCs or to pay the basic allowance. For example, only 1.4 per cent of the SOEs in Heilongjiang Province were able to clear their debts and pay workers compensation (Zhao et al., 2002), and most laid-off workers actually failed to receive their basic living allowance. A national survey of all stateowned single-venture enterprises in 1997 found that most laid-off workers did not enter RSCs and that half of them received no allowance (Solinger, 2002). In 1998, Chinese Labour Statistics showed that 32 per cent of 282,000 workers from 121 bankrupted SOEs were not receiving the basic allowance (Zhao et al., 2002).

Furthermore, the amount of laid-off workers' living allowance was too small to meet their basic needs. According to central government policy, local authorities could determine the levels of the basic living allowance according to local financial conditions. As a consequence, laid-off workers experienced a big drop in their benefits, some receiving only 60 per cent of their normal salaries (China Labour News, 1995a), and some even received less. In Wuhan City, the standard allowance for laid-off workers in 2000 was $¥ 280$, which was 'hardly enough for eking out an existence' (Solinger, 2002: 317).

In addition to the laid-off workers, SOE reform also created financial uncertainties for retired workers and those who were still working. As a result of the SOEs' financial difficulties, many workers experienced unpaid wages, many retired workers did not receive their pensions, and a large number of unemployed workers received no unemployment benefits. China Labour News (1995c) reported that 26 enterprises in a city of Hunan Province failed to pay $¥ 6.5$ million in old-age insurance premiums for more than a year. An official 1995 survey found that 21 per cent of 2,188 respondents in four cities had experienced pay arrears 
(China Labour News, 1995b). Nationally, 24,214 SOEs failed to pay wages and pensions to 3.5 million workers for several months in 1996 (Chen, 2000), and 31 per cent of the laid-off workers from small SOEs and 8 per cent of those from large SOEs received no unemployment subsidies in 1997 (Cai, 2002). Table 1 shows the extent of wage and pension arrears.

[Insert Table 1]

SOE reform directly accelerated China's urban poverty. In 1997, 39 per cent of its urban households suffered a loss of income (Plone Foundation, 2008). After examining the extent of poverty in 13 cities, Li (2002) estimated that 23 million, or about 5.9 per cent, of China's urban residents lived in poverty in 1999. He further pointed out that the number of poor people increased by 10 per cent between 1995 and 1999, and that families which had members being laid off or unemployed were six times more likely to live below the poverty line than other families. He concluded that 'urban poverty has become more widespread and serious'.

Furthermore, 67 per cent of the laid-off workers in 10 cities were in debt and 31 per cent had no income (Chen, 2000). Wang and Zhang estimated that 1.9-2.5 million urban older people were living in poverty, with a poverty incidence of 4.2-5.5 percent (Wang, 2005). This clearly shows that many workers faced enormous financial pressures as a result of unemployment, reduced incomes and unpaid salaries, and that a subsistence crisis (Chen, 2000), and not workers chasing better lifestyles, was causing social unrest in urban China. SOE reform therefore inevitably caused confrontations between workers and the government. Laid-off workers' legitimate claims for unpaid living allowances and pensions weakened the government's authority. They became a powerful force, as massive lay-offs 
broke the division between skilled and unskilled workers and permanent and temporary ones, creating a sense of collective grievance that united a large number of workers through their sharing of common concerns (Chen, 2000). Many affected workers had little choice but to take aggressive actions in order to fight for their survival needs. As one protestor emphasised, 'Since our rice bowl has been broken, what else have we to fear?' (Chen, 2000: $60)$.

From 1993 to 1997, social unrest in China increased from 8,700 to 15,000 cases, or by nearly 90 per cent (Keidel, 2005), and an average of nearly 1.3 million workers were involved in labour-related demonstrations annually between 1992 and 1997 (Chen, 2003). The South China Morning Post reported that such incidents rose to 3.6 million workers in 1998 (cited in Chen, 2003: 239).

More seriously, some workers took such more radical actions as 'blocking highways, railways or bridges' (Cai, 2002: 342). For example, more than 300 miners in Liaoning Province blocked the local highway to protest against wage arrears in August 1994; about 1,000 workers in the city of Zigong in Sichuan Province participated in a demonstration to express their anger at year-long wage arrears and the suspension of medical-fee reimbursements in October 1997; and 1,000 workers from a Hunan television factory blocked a key highway in September 1998, demanding the payment of their wages (Chen, 2000).

Workers were generally unsatisfied with their wages, benefits, pensions, unemployment compensation and working conditions (Chen, 2003). Unpaid salaries were one of the key factors triggering the conflicts, with more than 80 per cent of the conflicts between employers and employees in 1996 being related to pay arrears (China Labour News, 1996). In the same year in the city of Shenzhen, for example, 12,000 workers suffered pay arrears involving more than $¥ 8.3$ million (China Labour News, 1996). The reduction in workers’ 
benefits was another key factor causing confrontations, with contractual conflicts causing more than 300 strikes in 1996 (China Labour News, 1996). The curtailment of workers' rights caused 37.7 per cent of the labour conflicts in Henan Province in 1997 (Chen, 2003).

The Chinese government therefore regarded urban workers as 'the biggest threat to social stability' (Plone Foundation, 2008). Urban workers were more educated, had a greater sense of entitlement, and had better access to communication with reporters, intellectuals and lawyers than peasants (Lum, 2006). Cai (2002) found that some organisers of labour protests had previously occupied prestigious and influential positions in both SOEs and the Chinese Communist Party (Table 2). They also had much experience with dealing with enterprise authorities and the government. These organisers were willing to take risky action because of 'a combination of their personal stake in the action, community pressure, and sometimes a sense of justice' (Cai, 2002: 335).

The SOE reforms had threatened the livelihoods of devoted members of the CCP as well as common workers. As a result, the Chinese leadership faced strong resistance from the victims of the economic reforms. In particular, the deterioration of the welfare functions of work units directly eroded the foundations of the government's political control over the lives of SOE workers. The Chinese government therefore needed to establish new forms of welfare protection in order to regain its control over the workers.

[Insert Table 2]

\section{Legitimacy and the urban MSLS}

Social stability is the Chinese government's 'paramount concern' (Chen, 2003: 254). The frustrated workers' protests and demonstrations had weakened the Chinese leadership's authority and rocked the foundation of a stable society, but the leadership found it difficult 
to use military power to suppress the workers' actions because of the legitimacy of their demands. Chen noted that:

crackdowns against people who make no political claims and only demand a minimum livelihood would place the government in a morally and politically indefensible position. Suppressing these protects would make the government look indifferent to the condition of the working class, and cause even greater resentment among workers. (2000: 61)

As brutal suppression was unlikely to be a realistic option, the Chinese leadership tried to pacify the workers by addressing their welfare concerns. Jiang Zemin, then China's president, urged his government to accelerate social security reform in order to provide a supportive environment for reforming SOEs and securing social stability (China Labour News, 1997). The State Council, China's top administrative unit, announced the implementation of the MSLS in all cities in 1997 in order to address these political and economic considerations. As the State Council emphasised, the MSLS's establishment was to help 'safeguard social stability and facilitate economic reform' (State Council, 1997).

It should be noted that one of the key functions of the MSLS was to give extra support to laid-off and retired workers whose SOEs had inadequately addressed their financial needs. As the State Council stressed, the MSLS provided assistance for families which were still in financial difficulties despite having received the basic living allowance and pensions (State Council, 1997). This means that the MSLS was an additional compensation package from the Chinese government for poor, laid-off workers who had previously received comprehensive services from their SOEs. 
Another official notification in 2000 revealed the importance of the MSLS to China's social stability and smooth economic transition when the State Council (2000) announced that the MSLS was a key component of China's social security system, which had 'an important meaning to improve the contents of a socialist market system, maintain social stability, and safeguard the successful reform of the SOEs and the nation's long term rule and safety'. The State Council further explained the relationship between laid-off workers and the MSLS by proclaiming that:

SOEs have to terminate the employment contracts with workers who reach the maximum period but still fail to get jobs. The workers are entitled to unemployment benefits. However, if they reach the maximum period of receiving the unemployment benefits, the Ministry of Civil Affairs have to provide them with the MSLS. (State Council, 2000)

Obviously, the state constructed the MSLS as a safety net through which the SOEs' traditional welfare obligations to their workers could be transferred from individual enterprises to a new public assistance scheme. Table 3 shows that as many as 80.3 per cent of the MSLS's recipients in 2002 were laid-off workers, unemployed workers and dependants of laid-off or unemployed workers. The MSLS had successfully become the last resort for the victims of China's enterprise reforms.

[Insert Table 3]

\section{Peasant unrest and the rural MSLS}

The establishment of the rural MSLS in 2007 was related to peasant unrest. Rural areas had become increasingly unstable over the previous three decades, with large-scale protests and violence breaking out against the 'extraction of excessive taxes and fees' (Bernstein, 2004: 2) 
and 'official corruption, land acquisition, and non-transparency in village affairs' (Chang, 2004). Peasants in China do not own their farmland but receive 30 -year contracts with the government for its use. They are also entitled to compensation according to their agricultural output and resettlement expenses when public land acquisitions occur (Lum, 2006).

However, many local officials ignored farmers' rights in the process of acquiring farmland by not conducting proper consultations or paying reasonable compensation. Land acquisitions had threatened the livelihood of many farmers and caused serious conflicts between them and local government officials. Between 1990 and 2002, 66.3 million farmers lost their land (Guo, 2005), with more than 3 million new victims each year since then (Jiang and Wen, 2007).

In most cases farmers received only a relatively small amount of compensation. Guo (2005) found that the compensation his 255 land-losing respondents in five cities received was only enough to sustain them for two and a half years. Many land-losing farmers encountered unemployment and poor living conditions. More than 10 million, or 20 per cent, of the landlosing farmers could not find new jobs (Jiang and Wen, 2007), and 46 per cent experienced a deteriorating quality of life (China Internet Information Centre, 2007). For example, the per capita income of land-losing farmers in Fujian Province dropped by 76.2 per cent, in Jiangxi Province by 75 per cent, and in the Guangxi Autonomous Region by 75.5 per cent (Jiang and Wen, 2007).

Land acquisitions also threatened the livelihood of older people. In 2000, 85 per cent of the older people in rural areas relied on family support, with only 5.4 per cent of them being protected by some kind of pension (Wang, 2006). This large number of unemployed landlosing farmers therefore severely weakened the financial base of elder care in rural China. 
About 30 million peasants were living under the poverty line in 2003 (China Internet Information Centre, 2003).

More seriously, illegal land acquisitions were common. According to the Ministry of Land and Resources, 53 per cent of all land acquisitions between October 2003 and September 2004 were illegal (China Daily, 2006). Local authorities were using illegal land acquisitions to raise revenues, with 60 per cent of their non-budgetary income coming from land deals and real-estate transactions (China Daily, 2006). The Ministry of Land and Resources further revealed that 73 per cent of the complaints it received in the first six months of 2002 were disputes concerning land acquisitions and the unlawful use of land. Similarly, the State Bureau for Letters and Calls found that 70 per cent of the 4,116 complaints it handled in 2004 were about land acquisitions.

As land acquisitions had directly destroyed their source of livelihood, the farmers affected had no choice but to take actions to defend their rights. The Rural Development Institute of the Chinese Academy of Social Sciences pointed out that the focus of peasant protests in recent years had shifted from tax problems to land disputes (Chang, 2004). Obviously, as with laid-off workers in cities, the farmer protests in the countryside resulted from a subsistence crisis.

The farmers' demands were narrow and specific. They included relief from oppressive burdens and more official accountability in regard to using public resources (Bernstein, 2004). Approximately 53,000 rural incidents involving more than five million peasants took place in 1999 (Bernstein, 2004). The Central Committee's Organisation Department noted in 2001 that hundreds of thousands of people were participating in protests, and that many of these protesters 'have leaders, are organised, and behind the participants there are core 
elements who exert influence and control. Some even hire lawyers and seek media support' (Bernstein, 2004: 2).

Guo (2005) noted that the peasants' reactions towards local governments' unreasonable land acquisitions and taxation measures were increasingly characterised by direct conflict and more collective, well-organised and persistent actions, and $\mathrm{Yu}(2003)$ reported that at least ten big protests had occurred in several parts of Hunan Province since the early 1990s, and that more than 10,000 peasants had been involved in two big incidents. Yu (2003) further stressed that these rural anti-government incidents featured (i) clear focuses, (ii) well-organised actions, (iii) the emergence of new and influential leaders, (iv) more physical conflicts and more violence, and (v) spreading to other regions.

Bernstein (2004) found that the leaders of farmers' protests in recent years were better educated and also understood national policy. They came mainly from three groups. These were 'respected villagers who did not hold office', 'village cadres and Party members', and 'elected village officials' (Bernstein, 2004: 7). More importantly, farmers had changed their strategies from previously peaceful tactics to violent ones (Yu, 2003), adopting the use of violent siege, armed resistance, and other hostile actions (Chang, 2004).

For example, (i) more than 2 million farmers established more than 300 organisations in 12 provinces and municipalities in October 2003, protesting with the slogan, 'Farmers are landowners, anti-suppression, anti-exploitation, and anti-fraud', (ii) more than 1,000 residents of the village of Mashan in Zhuhai City held a demonstration against unreasonable compensation for land acquisition in September 2004, blocking traffic for several days, and (iii) 60,000 residents of Hanyuan County in Sichuan Province staged protests against unreasonable relocation compensation in October 2004, destroying the offices of the county 
government and party committee and reportedly holding the Secretary of the Sichuan Provincial Committee against his will (Chang, 2004).

The Ministry of Public Security revealed that 87,000 peasant protests occurred in 2006 (Tran, 2006). The land-losing farmers were like a time bomb for the Chinese government (Muldavin, 2006). Seeing the danger that peasant protests posed for China's stability, some representatives from two official consultative bodies, the National People's Congress and the Political Consultative Conference, urged the central government to address the problems of land acquisitions immediately, explaining that 65 per cent of the conflicts between peasants and local authorities were about land acquisitions and resettlements (Bureau of Land Resources, 2006).

Pointing out the relationship between social unrest and social welfare provisions, Song and Yan (2006), two researchers from the Ministry of Public Security, noted that the 13 million laid-off workers and 40 million land-losing farmers had already become the two biggest disadvantaged groups in China, and that in regions where social security coverage was relatively low, 'the dissatisfaction of the deprived groups has been increasing. There are already conflicts in some regions ... If officials fail to handle their demands properly, some incidents will trigger a crisis that threatens the public's safety" (Song and Yan, 2006: 168). Similarly, Tran (2006) warned that the possibility of a peasant uprising throughout the country was 'a real one and should not be underestimated'.

The farmers' protests forced the Chinese government to make concessions. The central government has recently strengthened legal protection for farmers' land, abolished the agricultural tax, and increased welfare spending in rural areas (Lum, 2006). It admitted in a policy paper that urgent actions were necessary because 'some poor populations in rural areas still do not have sufficient clothing and enough food' (State Council, 2007). Against this 
background, the Council established a nationwide rural MSLS in 2007 as a long-term strategy for tackling rural poverty (State Council, 2007).

The rural MSLS had several implications. It was to provide compensation for land-losing farmers and to help reduce conflicts between rural residents and officials. After its implementation the number of recipients rose dramatically from 15 million in 2006 to 34.4 million in 2007, an increase of 129 per cent (People's Daily Online, 2008). However, some local officials may have manipulated it by using it as an excuse to continue to acquire farmland illegally. The scheme's launch also implied that the central government was taking a more preventive approach to consolidating its authority in the countryside in order to provide a more stable political environment for its economic reforms, emphasising that 'good agricultural industry and the countryside are two pillars for supporting China's economic growth and social stability' (Chinese Communist Party Central Committee and State Council [CCPCC], 2007). They obviously expected the rural MSLS to perform the dual function of securing political legitimacy and facilitating economic development.

\section{Conclusion}

This article has analysed the impact of social conflict on the development of China's public assistance schemes in both urban and rural areas. It has illustrated how the government mainly implemented the urban MSLS in 1997 in order to address urban workers' dissatisfactions following the introduction of its SOE reforms. The MSLS was strictly an urban-oriented welfare scheme that aimed at providing some form of compensation to laidoff and retired workers who had previously held prestigious positions in state enterprises. However, the state ignored rural residents' financial needs during the same period, only introducing a rural MSLS in 2007 after large-scale and violent peasant protests against rural 
poverty and unfair land acquisitions. Obviously, the establishment of the rural MSLS in 2007 could hardly be explained convincingly as the outcome of a ten-year social security experiment in urban areas. The development of the rural MSLS has clearly needed examination in the context of peasant unrest, deprivation and the increasing number of land acquisitions since the early 1990 s.

Legitimacy theory's explanation of social welfare's social-stability function can therefore improve our understanding of these phenomena. This article has therefore utilised this theory to show how the Chinese government's introduction of the MSLS in cities and the countryside was part of its strategy for minimising social conflicts and maintaining political legitimacy.

By focusing mainly on enhancing political legitimacy, the Chinese government offered poor people only a residual public assistance scheme. The MSLS's benefit levels barely meet its recipients' basic needs. The MSLS Ordinance of 1999 stated that 'the minimum living standard for urban residents is according to the basic necessities required in a city, including clothing, food, and housing. If possible, expenses for electricity, gas, and compulsory education for children can be taken into account' (State Council, 1999).

Obviously, it only considers a few items to be basic necessities, and excludes such essential items as medical care and special needs for disabled people and children. After examining the levels of the MSLS in 36 cities, Zhang and Tang (2005) found that the average amount of the MSLS benefit was only 9.2 per cent of the per capita monthly income of the cities studied. Also, the per capita monthly MSLS benefit was as low as 8.4 per cent of the per capita monthly expenditure on food in those 36 cities (Zhang and Tang, 2005). According to a vice-minister of the Ministry of Civil Affairs, the MSLS was only 'a basic survival line' (China 
Economic Net, 2007). This implies that poor people have to seek supplementary aid from relatives, friends, and charities in order to make ends meet.

Furthermore, the MSLS's application procedures fail to respect its claimants' privacy. The MSLS ordinance requires local governments to publish the details of applicants in the form of a public notice and to ask their neighbours for comments on the applicants' eligibility (State Council, 1999). The People's Daily (2002) reported that 'some families refuse to apply for assistance for fear of their children being discriminated against at schools'. Obviously, China's MSLS has been constructed to be a highly stigmatised scheme as well as a socially undesirable last resort.

The residual nature of China's social assistance scheme seems to be the result of its local authorities' financial limitations as well as the nature of a capitalist state. Many lower-tier authorities are in debt and have insufficient resources to finance the MSLS, the amount of debt for all village authorities in China being between $¥ 600$ billion and $¥ 1,000$ billion in 2004 (Zhu et al., 2006). Facing tremendous financial pressures, many local authorities pay low levels of assistance and set up stringent welfare criteria to control the number of applicants.

As China is now a mixed economy, its low benefit levels and stigmatised application procedures need to be analysed in the context of a capitalist state's legitimation and accumulation functions. Social security can perform a social control function that 'specifically directs individual behaviour' (Dean, 1991: 29). Dean also asserted that the preoccupations of social security policy and the rules of the social security systems are 'highly effective in identifying and marginalising the poor so that they appear as a "claiming class" or "underclass"' (1991: 9). The marginalisation of welfare claimants and the constraints placed over their freedom help to protect the work ethic of a market economy. Piven (1973: 271) stressed that a capitalist welfare system 'must restore people to work roles', and that one of 
the functions of public assistance arrangements should be to regulate the behaviour of poor people. The miserable conditions in nineteenth-century workhouses, she argued, were 'intended to ensure that no one with any conceivable alternatives would seek public aid' (Piven, 1973: 286).

China has therefore constructed the MSLS to be a minimal and stigmatised scheme which only provides temporary financial support for those who are unable to stand on their own feet. As a MSLS policy paper clearly stated, the level of the MSLS should be below the level of unemployment benefits, which should be lower than the minimum wage (State Council, 1999). Thus, the Chinese government's basic approach to social assistance is to minimise public expenditure and to 'sustain the work ethic rather than to tackle poverty and inequality' (Chan et al., 2008: 198).

In conclusion, the foundation of China's stability is still relatively fragile due to its low levels of public assistance and other poor social services. For example, the National Health Services Survey showed that in 2003 nearly half of respondents who had suffered health problems 'did not visit doctors for recommended treatment' and more than 10 per cent of patients 'did not have any treatment' because of financial difficulties (Zhao, 2006). Another study reported that of the 569 respondents in Kunming city in 2007, 58 per cent of them were dissatisfied/very dissatisfied with the affordability of public health care delivery (Jiang et al. 2009). Thus, significant improvement in China's public health care delivery is urgent. By maintaining long-term political stability, China's leadership needs to raise the MSLS recipients' benefits and also improve the public's accessibility to other basic services. Nevertheless, despite its weaknesses, the MSLS has fulfilled its welfare and social stability roles during China's critical reform period by addressing the survival needs of laid-off workers and land-losing farmers. By establishing the MSLS the Chinese government has both 
reduced the resistance of laid-off workers and land-losing farmers, maintaining the work ethic for its mixed economy.

\section{References}

American Chronicle (2009) 1978-2008: China, Changing Course Like the Yellow River. (http://www.americanchronicle.com/articles/view/84086).

Bernstein, T. P. (2004), Unrest in Rural China: A 2003 Assessment, Irvine: University of California.

Best, S. (2002), Introduction to Politics and Society, London: Sage.

Bureau of Land Resources (2006), The Livelihood of Land-losing Peasants, 15 March (http://www.zjglr.gov.cn/xwlm/200631584827.html).

Cai, Y. (2002), 'The resistance of Chinese laid-off workers in the reform period', The China Quarterly, 170, 327-44.

CCPCC (Chinese Communist Party Central Committee) (1993), Decision on Issues Concerning the Establishment of a Socialist Market Economic Structure, Passed by the Third Plenary of the Fourteenth Central Committee's Meeting on 14 November, Beijing: CCPCC.

CCPCC (Chinese Communist Party Central Committee) and State Council (2007), Views on Facilitating the Development Socialist New Rural Areas, Beijing: CCPCC \& State Council.

Chan, C. K., Ngok, K. L. and Phillips, D. (2008), Social Policy in China: Development and WellBeing, Bristol: Policy Press.

Chang, C. C. (2004), 'Rural protests and farmers' rights', Taiwan Perspective, Taipei: Institute for National Policy Research (http://www.tp.org.tw/document/detail.htm?id=20012019).

Chen, A. (2004), 'China's urban housing: privatization and market integration', in A, Chen, G. Liu and K., Zhang (eds.), Urbanisation and Social Welfare in China, Surrey: Ashgate.

Chen, F. (2000), 'Subsistence crises, managerial corruption and labour protests in China', The China Journal, 44, 41-63.

Chen, F. (2003), 'Industrial reconstructuring and workers' resistance in China', Modern China, 29:2, 237-62. 
China Daily (2006), 'Stop illegal land use', 8 June (http://www.china.org.cn/english/GSe/170761.htm).

China Economic Net (2007), Vice Minister of the Ministry of Civil Affairs: The Rural Minimum Standard of Living Scheme should prevent unlawful practices, 1 August (http://www.ce.cn/cysc/agriculture/gdxw/200708/01/t20070801 12382976.shtml).

China Internet Information Centre (2003), China to extend minimum living subsidy to rural poorest, 9 October.

China Internet Information Centre (2007), Urbanisation should not bring harmful effects on peasants, 26 January (http://www.china.com.cn/news/txt/2007$\underline{01 / 26 / \text { content 7718582.htm). }}$

China Labour News (1995a), Punishments brought by the older system, 18 May.

China Labour News (1995b), Important statistics of this survey, 1 January.

China Labour News (1995c), Supervising order issued to enterprises which did not pay premium, 10 June.

China Labour News (1996), Open a protective umbrella for workers facing salary arrears, 7 December.

China Labour News (1997), Jiang Zemin visited SOE workers, 18 January.

Choi, C. H. and Roy, P. C. (2006), Economic Reform in China and India: Development Experience in a Comparative Perspective, Cheltenham: Edward Elgar Publishing.

Chow, G. C. (1994), Understanding China's Economy, New Jersey: World Scientific Publishing Co.

Chow, G. C. (1999), China's Economy, Reform and Perspectives (http://www.princeton.edu/ gchow/China.html).

Chua, B. H. (1997), Political Legitimacy and Housing: Stakeholding in Singapore, London: Routledge.

Dean, H. (1991), Social Security and Social Control, London: Routledge.

Ding, X. L. (1994), The Decline of Communism in China: Legitimacy Crisis 1977-1989, Cambridge: Cambridge University Press. 
Euromonitor International (2007), China's middle class reaches 80 million, 25 July (http://www.euromonitor.com/Chinas_middle_class_reaches_80_million).

Gang, F., Lunati, M. R. and O'Connor, D. (1998), Labour Market Aspects of State Enterprise Reform in China, Paris: OECD Development Centre.

Gao, S. (1999), Two Decades of Reform in China, California: World Scientific.

Green, S. (2004), Enterprise Reform and Stock Market Development in Mainland China, Frankfurt: Deutsche Bank Research.

Gries, P. H. and Rosen, S. (2004), 'Introduction: Popular protect and state legitimation in $21^{\text {st }}$ century China', in P. Gries and S. Rosen (eds), State and Society in $21^{\text {st }}$ Century China: Crisis, Contention and Legitimation. New York: Roultedge Curzon.

Guo, B. (2003), 'Political legitimacy and China's transition', Journal of Chinese Political Science, 8: 1\&2, 2-25.

Guo, X. (2005), Urbanisation and Compensation and Resettlement of Land-Losing Peasants (http://www.zhinong.cn/data/detail.php?id=4336).

Habermas, J. (1976), Legitimation Crisis, London: Heinemann Educational Books.

Hong Kong Trade Development Council (2001), Vice Minister of the Ministry of Labour and Social Security Wang Tung, 11 June (http://www.tdctrade.com/report/top/top_010605.htm).

Jiang, L. and Wen, X. (2007), Comparing the Living Conditions of Land-losing Peasants in Eastern, Central, and Western Regions (http://www.ccrs.org.cn/show.aspx?id=857). Jiang, L., Gan, C., Kao, B., Zhang, Y., Zhang, H. and Cai, L. (2009). 'Consumer satisfaction with public health care in China', Journal of Social Sciences, 5:3, 223-235.

Keidel, A. (2005), 'The economic basis for social unrest in China', The Third EuropeanAmerican Dialogue on China, The George Washing University, May 26-27.

Kluver, A. (1996), Legitimating the Chinese Economic Reforms: A Rhetoric of Myth and Orthodoxy. Albany: Stat University of New York Press.

Lam, W. L. (2006), Chinese Politics in the Hu Jintao Era: New Leaders, New Challenges, New York: An East Gate Book.

Leung, J. and Nann, R. (1995), Authority and Benevolence, Hong Kong: The Chinese University Press and St Martin's Press. 
Li, S. (2001), 'Bankruptcy law in China: lessons of the past twelve years', Harvard Asia Quarterly, 5: 1 (www.asiaquarterly.com/content /view/95/40/).

Li, S. (2002), The Patterns and Causes of Poverty in China

(http://unpan1.un.org/intradoc/groups/public/documents/APCITY/UNPAN011949.pdf).

Lou, J. (1998), 'Comments on chapter: equality and growth in developing countries: old and new perspectives on the policy issues', in V. Tanzi and K, C. (eds.), Income Distribution and High-quality Growth, Massachusetts: MTI Press.

Lum, T. (2006), Social Unrest in China, Cornell University ILR School (http://digitalcommons.IIr.cornell.edu/crs/19).

Ministry of Health (2006), China's Annual Health Statistics 2004, Ministry of Health of the PRC (www.moh.gov.cn/statistics/digest06/y25.htm).

Muldavin, J. (2006), 'The environmental and social outcomes of China's reforms: Challenges to state legitimacy', The US-China Economic and Security Review Commission Hearing on Major Internal Challenges Facing the Chinese Leadership, 3 February.

Nielsen, I., Smyth, R. and Zhang, M. (2005), Unemployment with China's Floating Population: Empirical Evidence from Jiangsu Survey Data, Monash University, Monash.

O'Connor, J. (1973), The Fiscal Crisis of the State, New York: St. Martin's Press.

Offe, C. (1984), Contradictions of the Welfare State, London: Hutchinson.

Otsuka, K., Liu, D. and Nurakami, N. (1998), Industrial Reform in China: Past Performance and Future Prospects, Oxford: Oxford University Press.

People's Daily (2002), Urban needy: The new concern of Chinese government, 3 November.

People's Daily Online (2006), More than nine percent of Chinese school-age migrant children out of school, 10 December

(http://english.people.com.cn/200612/10/eng20061210_330847.html).

People's Daily Online (2008), The Ministry of Civil Affairs reported the development of civil affairs in 2007, 24 January (http://politics.people.com.cn/BIG5/6817546.html).

Piven, F. (1973), 'The relief of welfare', in M. Pilisuk and P. Pilisuk (eds.) How We Lost the War on Poverty, Transaction Publishers. 
Plone Foundation (2008), The Generation of Unhappy Workers: Situation and Protests of Urban Workers and Un-employed (http://www.prolposition.net/nl/2008/10/unhappy\%20workers).

Pusey, M. (1987), Jurgen Habermas, Oxford: Taylor \& Francis.

Qian, Y. (1999), 'The process of China's market transition (1978-98): The evolutionary, historical, and comparative perspectives', Journal of Institutional and Theoretical Economics Symposium on Big-Bang Transformation of Economic Systems as a Challenge to New Institutional Economics, June 9-11, Wallerfangen/Sarar, Germany.

Qian, Y. and Wu, J. (2003), 'China's transition to a market economy: how far across the river?' in N. Hope, D. Yang, M. Yan and M. Li (eds.), How Far Across the River? California: Stanford University.

Shang, X. and Wu, X. (2004), 'Changing approaches of social protection: social assistance reform in urban China', Social Policy \& Society, 3:3, 259-71.

Shin, D. M. (2003), Social and Economic Policies in Korea: Ideas, Networks and Linkages, London: RoutledgeCurzon.

Shue, V. (2004), 'Legitimacy crisis in China?', in P. Gries and S, Rosen (eds.), State and Society in $21^{\text {st }}$-Century China: Crisis, Contention, and Legitimation, Routledge.

Solinger, D. (2002), 'Labour market reform and the plight of the laid-off proletariat', The China Quarterly, 170, 304-26.

Song, E. and Yan, C. (2006), 'Public security in 2006', in X. Ru, X. Lu and P. Li (eds), Analysis and Forecast on China's Social Development (2007), Beijing: Social Sciences Academic Press.

State Council (SC) (1997), State Council's Announcement on Establishing a National Minimum Living System for Urban Residents (www.mca.gov.cn/article/content/WDB ZCWJ/2003/22484945.htm)(accessed: 10 October 2008).

State Council (SC) (1999), Ordinance on the Minimum Standard Living Scheme for Urban Residents, Document No 271, Beijing: SC.

State Council (SC) (2000), Notification on Doing Better Work on Providing Pensions for Retired Workers of the State-Owned Enterprises and Giving the Basic Living Allowance for Laid-Off Workers, Beijing: State Council. 
The Economist (2004), 'Behind the mask', 18 March

(www.economist.com/displaystory.cfm?story_id=2495113).

Tran, T. T. (2006), A new peasant revolution - is China learning from its past? Inside Asia, 1 June (http://insideasia.typepad.com/ia/2006/06/a new peasant r.html) .

Wang, D. (2006), 'China's urban and rural old age security system: Challenges and options', China \& World Economy, 14:1, 102-116.

Wang, D. W. (2005), China's Old Age Security in Cities and Countryside (www.labourecon.org/workingpaper/dw200508 cn.pdf).

White, G., Goodman, R. and Kwon, H. (1998), 'The politics of welfare in east Asia', in R, Maidment, D. Goldblatt and J, Mitchell (eds.), Governance in the Asia-Pacific, London: Routledge.

Wong, C. K., Lo, V. L. and Tang, K. L. (2005), China's Urban Health Care Reform: From State Protection to Individual Responsibility, Maryland: Lexington Books.

Yu, J. (2003), Political Crisis in China's Rural Areas: Patterns, Causes and Solutions (http://www.tianya.cn/publicforum/Content/develop/1/18086.shtml).

Zhang, S. F. and Tang, J. (2005), The Level of Minimum Standard of Living Scheme Just Only Enough for Food and Clothes, Beijing: Institute of Sociology of the Chinese Academy of Social Sciences (http://203.93.24.66/shxw/shzc/P020050908295415620463).

Zhao, Y., Liu, X. and Zhong, L. (2002), 'A magerialised life in city, tackling poverty cannot leave the government', Observation Weekly, 4 November (http://www.china.com.cn/chinese/difang/131075.htm).

Zhao, Z. (2006), 'Income inequality, unequal health care access, and mortality in China', Population and Development Review, 32: 3, 461-483.

Zhu, G., Tam, Q. and Zhang, J. (2006), Township Debts, Beijing: Social Sciences Academic Press.

Acknowledgement: 
I would like to express my gratitude to Dr Graham Bowpitt of Nottingham Trent University for his helpful comments and editorial assistance. Many thanks are also due to two anonymous reviewers for their comments on the article. 
TABLE 1. The ten provinces with the greatest wage and pension arrears at state and collective enterprises, 1994-95

\begin{tabular}{|l|l|l|l|l|l|l|}
\hline & \multicolumn{9}{|l|}{$\mathbf{1 9 9 4}$} & \multicolumn{2}{l|}{} \\
\hline Provinces & $\begin{array}{l}\text { No. of } \\
\text { enterprises } \\
\text { with wages } \\
\text { and pensions } \\
\text { in arrears }\end{array}$ & $\begin{array}{l}\text { No. } \\
\text { workers } \\
\text { affected }\end{array}$ & $\begin{array}{l}\text { No. of retired } \\
\text { workers } \\
\text { affected }\end{array}$ & $\begin{array}{l}\text { No. of } \\
\text { enterprises } \\
\text { with wages } \\
\text { and pensions } \\
\text { in arrears }\end{array}$ & $\begin{array}{l}\text { No. } \\
\text { workers } \\
\text { affected }\end{array}$ & $\begin{array}{l}\text { No. of retired } \\
\text { workers } \\
\text { affected }\end{array}$ \\
\hline Heilongjiang & 2,720 & 687,093 & 164,397 & 2,324 & 551,916 & Not available \\
\hline Liaoning & 1,734 & 511,947 & 138,040 & 1,823 & 477,839 & 127,080 \\
\hline Jilin & 1,255 & 226,692 & 70,088 & 1,423 & 212,093 & 37,151 \\
\hline Henan & 3,083 & 189,149 & 30,270 & 1,168 & 193,504 & 16,175 \\
\hline Hunan & 2,181 & 158,207 & 33,047 & 1,298 & 160,245 & 32,304 \\
\hline Hebei & 1,576 & 147,960 & 15,051 & 1,229 & 218,819 & 41,731 \\
\hline Shanxi & 1,167 & 118,349 & 21,850 & 636 & 139,830 & 24,550 \\
\hline Hubei & 1,264 & 100,709 & 14,917 & 536 & 79,795 & 13,920 \\
\hline Shannxi & 835 & 91,148 & 21,783 & 445 & 33,497 & 3,302 \\
\hline Sichuan & 913 & 90,926 & 21,387 & 688 & 101,130 & 109,411 \\
\hline
\end{tabular}

(Chen, 2000: 48.) 
TABLE 2. Types of organisers of Chinese workers' collective actions $(N=41)$

\begin{tabular}{|l|l|}
\hline Background of organisers & Number of cases \\
\hline Previous enterprise leaders & 12 (4 retired people) \\
\hline Party-member workers & 9 (4 retired people) \\
\hline Current enterprise leaders & 7 \\
\hline Military veterans & 4 \\
\hline Others & 9 \\
\hline Total & 41 \\
\hline
\end{tabular}

(Cai, 2002: 335)

TABLE 3. Categories of recipients of the MSLS, 2002

\begin{tabular}{|l|l|l|}
\hline Categories of recipients & Number & \% \\
\hline Laid-off workers & $6,970,000$ & 36.1 \\
\hline Unemployed workers & $2,990,000$ & 15.5 \\
\hline $\begin{array}{l}\text { Dependants of laid-off or unemployed } \\
\text { workers and others }\end{array}$ & $5,540,000$ & 28.7 \\
\hline Currently employed & $1,910,000$ & 9.9 \\
\hline Three NOs & 970,000 & 5.0 \\
\hline Retirees & 930,000 & 4.8 \\
\hline Total & $19,310,000$ & 100 \\
\hline
\end{tabular}

(Douji et al. 2002, cited in Shang and Wu, 2004: 269) 